\title{
Slovak Local Ewe's Milk Lump Cheese, a Source of Beneficial Enterococcus durans Strain
}

\author{
Andrea Lauková ${ }^{1, *(\mathbb{D})}$, Martin Tomáška ${ }^{2} \mathbb{D}$, Vladimír Kmet' ${ }^{1}$, Viola Strompfová ${ }^{1}$, Monika Pogány Simonová ${ }^{1} \mathbb{D}$ \\ and Emília Dvorožňáková 3
}

1 Institute of Animal Physiology, Centre of Biosciences of the Slovak Academy of Sciences, Šoltésovej 4-6, 04001 Košice, Slovakia; kmetv@saske.sk (V.K.); strompfv@saske.sk (V.S.); simonova@saske.sk (M.P.S.)

2 Dairy Research Institute, a.s., Dlhá 95, 01001 Žilina, Slovakia; tomaska@vumza.sk

3 Parasitological Institute of the Slovak Academy of Sciences, Hlinkova 3, 04001 Košice, Slovakia; dvoroz@saske.sk

* Correspondence: laukova@saske.sk

check for updates

Citation: Lauková, A.; Tomáška, M.; Kmet', V.; Strompfová, V.; Pogány Simonová, M.; Dvorožňáková, E. Slovak Local Ewe's Milk Lump Cheese, a Source of Beneficial Enterococcus durans Strain. Foods 2021, 10, 3091. https://doi.org/10.3390/ foods10123091

Academic Editors: Javier Carballo and Juan Antonio Centeno

Received: 18 November 2021 Accepted: 10 December 2021 Published: 13 December 2021

Publisher's Note: MDPI stays neutral with regard to jurisdictional claims in published maps and institutional affiliations.

Copyright: (c) 2021 by the authors. Licensee MDPI, Basel, Switzerland. This article is an open access article distributed under the terms and conditions of the Creative Commons Attribution (CC BY) license (https:/ / creativecommons.org/licenses/by/ $4.0 /)$.

\begin{abstract}
Slovak ewe's milk lump cheese is produced from unpasteurized ewe's milk without any added culture. Because of the traditional processing and shaping by hand into a lump, this cheese was given the traditional specialty guaranteed (TSG) label. Up till now, there have existed only limited detailed studies of individual microbiota and their benefits in ewe's milk lump cheese. Therefore, this study has been focused on the beneficial properties and safety of Enterococcus durans strains with the aim to contribute to basic dairy microbiology but also for further application potential and strategy. The total enterococcal count in cheeses reached $3.93 \mathrm{CFU} / \mathrm{g}(\log 10) \pm 1.98$ on average. Based on a MALDI-TOF mass spectrometry evaluation, the strains were allotted to the species E. durans (score, 1.781-2.245). The strains were gelatinase and hemolysis-negative ( $\gamma$-hemolysis) and were mostly susceptible to commercial antibiotics. Among the strains, E. durans ED26E/7 produced the highest value of lactase enzyme $\beta$-galactosidase $(10 \mathrm{nmoL})$. ED26E/7 was absent of virulence factor genes such as $\mathrm{Hyl}$ (hyaluronidase), IS 16 element and gelatinase (GelE). To test safety, ED26E/7 did not cause mortality in Balb/c mice. Its partially purified bacteriocin substance showed the highest inhibition activity/bioactivity against Gram-positive indicator bacteria: the principal indicator Enterococcus avium EA5 (102,400 AU/mL), Staphylococcus aureus SA5 and listeriae $(25,600 \mathrm{AU} / \mathrm{mL})$. Moreover, 16 staphylococci (out of 22$)$ were inhibited (100 AU/mL), and the growth of 36 (out of 51) enterococcal indicators was as well. After further technological tests, E. durans ED26E/7, with its bacteriocin substance, can be supposed as a promising additive to dairy products.
\end{abstract}

Keywords: bioactivity; Enterococcus durans; safety; ewe's milk lump cheese

\section{Introduction}

Ewe's milk and cheeses made from it have a high nutritive value, which has led to high demand for those products that is increasing worldwide [1,2]. The indigenous microbiota in raw milk plays an important role in the cheese formation quality [3]. In general, cheese is composed of microbiota originating from the raw ingredients used, the environment and in some types of cheese, the added starter cultures or adjunct cultures. These many sources of microbiota cause considerable variability in the microbiome across cheese varieties [4]. Based on newly developed modern identification techniques, the microbiota of cheeses can be studied in more detail [4-6]. Recently, Parente et al. [7] reported a review study associated with the microbiota of dairy milk. Based on meta-analysis results, it was concluded that four phyla, such as Firmicutes, Proteobacteria, Bacteroidetes and Actinobacteria, included the majority of the most abundant and prevalent taxa identified in milk. There were detected psychrotrophs, bacteria associated with teat skin, with gut and also potentially beneficial lactic acid bacteria (LAB) [4-7]. In general, LAB are considered 
food-grade bacteria that are safe to consume. Among LAB, the representatives of the genus Enterococcus are found in many food products; these foods are animal-derived, e.g., dairy products [8-10]. The most frequently detected enterococcal species in cow, goat and ewe raw milk are Enterococcus faecium, E. faecalis, E. hirae and/or E. durans [7-10]. The safety approach for enterococci is controversial; they are considered as indicators of a hygiene condition [11,12]; but on the other side, many enterococcal strains possess beneficial properties, and they are even able to produce antimicrobial substances, enterocins, which also showed several beneficial effects in food [13-15] and/or influences in foodproducing animals [16,17]. Lauková et al. [16] reported the antimicrobial activity of Ent M in feces and caecum of broiler rabbits against pseudomonads and coliforms $(p<0.05)$, and also higher average daily weight gains were detected. Using Ent 2019 and its producing strain E. faecium EF2019 = CCM7420, a tendency to modulate the serum biochemistry parameters and to improve immunity, jejunal morphometry, weight gains, feed conversion and meat quality was reported [17]. The most frequently studied from this aspect are strains of the species E. faecium [16-18]. However, representatives of E. durans species have begun to be studied as beneficial microorganisms $[19,20]$. E. durans is grouped in the E. faecium group/cluster based on gene similarity $16 \mathrm{~S}$ rRNA analysis [21]. Similarly, formerly mentioned, the most frequently present enterococcal species in dairy products are involved in this cluster. Some E. durans strains are able to produce bacteriocinsdurancins [20,22-24]. Yanagida et al. [20] described durancin L28-1A as a new bacteriocin from E. durans L28-1 isolated from soil. It shows antibacterial activity against lactobacilli, lactococci, carnobacteria and Weissella spp. Durancin TW-49M was characterized as a novel non-pediocin-like Class II bacteriocin produced by E. durans QU49 from carrot [22]. El Quardy Khay et al. [23] described bacteriocin-producing strain E. durans E204 from camel milk. Anti-listerial activity in ham due to bacteriocin produced by E. durans 152 from a floor drain sample was reported by Lihui Du et al. [24].

Slovak ewe's milk lump cheese is a popular food article among the population in Slovakia. It is produced from unpasteurized ewe's milk without any added culture. Ewe's milk lump cheese should contain at least $47 \%$ dry matter and $52 \%$ fat in dry matter. Its processing was described in more detail in our previous study [5,25]. The final cheese is slightly acidic. This cheese was given the traditional specialty guaranteed (TSG) label [26] because of the traditional processing and shaping by hand into a lump. However, up till now, the study of individual microbiota in ewe's milk lump cheese has been looked at in limited detail. Therefore, this study has been focused on E. durans strains isolated from ewe's milk lump cheese and especially on beneficial properties (useful enzymes, bacteriocin activity) and safety of the strain E. durans ED26E/7 (e.g., virulence factor gene) with the aim to contribute to basic dairy microbiology but also for its further application as an additive. The novelty of this study lies in the fact that E. durans from Slovak local ewe's milk lump cheese has not been characterized up to now from this aspect. Therefore, knowing its beneficial potential brings a promising perspective for dairy processing, which indicates a practical aspect of the study.

\section{Materials and Methods}

\subsection{Source of Milk and Cheese Samples}

Thirty-eight (38) ewe's milk lump cheeses were sampled. Cheeses were made from milk of the Valachian breed, the most represented sheep breed in Slovakia [2]. This breed is mostly kept in mountain areas and is considered a multi-purpose breed for milk (cheese) production [27]. Cheese samples were supplied during the main production season by different agrofarms (34) in central Slovakia. The farms raise sheep that are grazed in one flock in a wild pasture all day, and they are kept in enclosures at night and during milking, as previously described by Kováčová et al. [2].

The processing of ewe's milk to manufacture milk lump cheese has already been described in our previous study [5]. Briefly, milk lump cheese manufacture involves several phases, such as making cheese curd, treating raw material, lump forming and 
dripping [28]. Each lump is left dripping at a temperature of $18-20{ }^{\circ} \mathrm{C}$ for $10-24 \mathrm{~h}$ and placed on a shelf at $13-15^{\circ} \mathrm{C}$ with sufficient ventilation. After three days, a slight skin covering is formed, and small grain-sized holes are developed inside the cheese. The taste of the final cheese is slightly acidic [28].

\subsection{Isolation and Identification of Enterococcus durans}

Cheese samples were treated by the standard microbiological method (International Organization for Standardization); $10 \mathrm{~g}$ of each cheese sample in $90 \mathrm{~mL}$ of Ringer solution (Merck, Darmstadt, Germany) was stirred using the Stomacher-Masticator (Spain) and diluted. The appropriate dilutions were plated on Slanetz-Bartley agar and M-Enterococcus agar (Difco, MD, USA). The plates were incubated at $37^{\circ} \mathrm{C}$ for $48 \mathrm{~h}$. Fifty-nine (59) presumed colonies were streaked on Brain heart agar (Difco, MD, USA) enriched with defibrinated sheep blood (5\%) to check their purity. Pure colonies were submitted for identification using MALDI-TOF mass spectrometry based on protein "fingerprints" [29] (MALDI-TOF MS, Bruker Daltonics, Billerica, MA, USA), performed using a Microflex MALDI-TOF mass spectrophotometer previously described by Lauková et al. [30]. Lysates of bacterial cells were prepared according to the producer's instruction (Bruker Daltonics, Billerica, MA, USA). The results evaluation was performed using the MALDI Biotyper 3.0 (Bruker Daltonics, Billerica, MA, USA) identification database. Taxonomic allocation was evaluated on the basis of highly probable species identification (score 2.300-3.000), secure probable species identification/probable species identification (2.000-2.299) and probable genus identification (1.700-1.999). Positive control was strain involved in the identification system database (E. durans DSM 20633T DSM). Identical colonies evaluated by the MALDI-TOF score value were excluded. Identified strains were maintained on M-Enterococcus agar (Difco, MD, USA-ISO 7899) for the next testing and also stored using the Microbank system (Pro-Lab Diagnostic, Richmond, BC, Canada).

\subsection{Phenotypization and Enzyme Production of E. durans}

Phenotypization of E. durans strains was performed based on consensus matrix of tests for identification of Enterococcus spp. as reported by Manero and Blanch [31], also involving the Rapid ID Streptotest (R Inc., Reading, PA, USA), as well as the API-ZYM system (BioMérieux, France). The testing panel involves arginine, esculin, mannitol, sorbitol, raffinose, inulin, galactose, glucose, NAG ( $N$-acetyl-glucosamine), hippurate hydrolysis, etc. Type strain E. durans ATCC 19432 was used as a control.

The following enzymes were tested using the API-ZYM system: alkalic phosphatase, esterase, esterase lipase (C8), lipase (C14), leucine arylamidase, valine arylamidase, cystine arylamidase, trypsin, $\alpha$-chymotrypsin, acidic phosphatase, naphtol-AS-B1-phosphohydrolase, $\alpha$-galactosidase, $\beta$-galactosidase, $\beta$-glucuronidase, $\alpha$-glucosidase, $\beta$-glucosidase, $N$-acetyl$\beta$-glucosaminidase, $\alpha$-mannosidase and $\alpha$-fucosidase. Enzyme activities were evaluated according to the manufacturer's recommendations (after $4 \mathrm{~h}$ of incubation at $37^{\circ} \mathrm{C}$ ). Color intensity values from 0 to 5 and relevant values in nanomoles (nmoL) were assigned for each reaction according to the color chart supplied with the kit.

\subsection{Hemolysis, Gelatinase Activities and Antibiotic Profile}

Hemolysis was detected by streaking the cultures on MRS agar (Difco) supplemented with $5 \%$ of defibrinated sheep blood. Plates were incubated at $37^{\circ} \mathrm{C}$ for $24-48 \mathrm{~h}$ under semi-anaerobic conditions. The presence or absence of clearing zones around the colonies was interpreted as $\beta$-hemolysis and negative $\gamma$-hemolysis, respectively [32].

Gelatinase is a proteolytic enzyme (extracellular metalloendopeptidase EC 3.4.24.30) that acts on a variety of substrates, such as insulin-beta chain, collagenous material in tissues, the vasoconstrictor endothelin-1, as well as sex-pheromones and their inhibitor peptide [33]. Gelatinase activity was detected with a 3\% gelatin medium (Todd-Hewitt agar, Becton and Dickinson, Cockeysville, MD, USA). After the growth of tested strains 
$\left(48 \mathrm{~h}\right.$ at $\left.37^{\circ} \mathrm{C}\right)$, plates were flooded with a $15 \%$ solution $\left(\mathrm{HgCl}_{2}\right.$ in $\left.20 \% \mathrm{HCl}\right)$. The loss of turbidity halos around colonies was then checked at $4{ }^{\circ} \mathrm{C}$ [34].

The antibiotic phenotype was tested using two methods; the disk diffusion method [35], as well as according to EFSA rules using strips [36] with minimal inhibitory concentration (MIC in $\mu \mathrm{g}$ ). In both cases, Mueller-Hinton agar enriched with defibrinated sheep blood was used (Difco). The control strain was E. faecium CCM4231 [37]. Antibiotic disks included clindamycin (Da, $2 \mu \mathrm{g})$, novobiocin ( $\mathrm{Nv}, 5 \mu \mathrm{g})$, ampicillin (Amp, $10 \mu \mathrm{g}$ ), erythromycin, azithromycin (15 $\mu \mathrm{g}, \mathrm{E}, \mathrm{Azm})$, streptomycin (S, $25 \mu \mathrm{g})$, chloramphenicol, kanamycin, vancomycin, tetracycline and rifampicin (C, Kan, Van, Tct, R, $30 \mu \mathrm{g}$ ). Antibiotic disks were supplied by Becton and Dickinson (Cockeysville, MD, USA) and Oxoid (Lowell, MA, USA) as well. Inhibition zones (in $\mathrm{mm}$ ) were evaluated according to the manufacturer's instructions. Following the strip method, the strips used were: ampicillin $(0.015-256 \mu \mathrm{g} / \mathrm{mL})$, penicillin $(0.032-34 \mu \mathrm{g} / \mathrm{mL})$, Tct $(0.015-256 \mu \mathrm{g} / \mathrm{mL}), \mathrm{E}$ $(0.015-256 \mu \mathrm{g} / \mathrm{mL})$ and Van $(0.015-256 \mu \mathrm{g} / \mathrm{mL})$. The E. faecalis strain ATCC 29212 was a positive control.

\subsection{Structural Enterocin Genes Analysis}

To detect structural enterocin genes in $E$. durans strains, the most frequently detected genes for enterocins production were analyzed: Ent A, P, B, L50B $[38,39]$. The primers for durancin were not available for testing. Primers sequences for PCR amplification of Ents genes were used according to Aymerich et al. [40], Casaus et al. [41] and Cintas et al. [42,43]: 5 min denaturation at $95^{\circ} \mathrm{C}, 30$ cycles $30 \mathrm{~s}$ at $95{ }^{\circ} \mathrm{C}, 30 \mathrm{~s}$ at $58{ }^{\circ} \mathrm{C}, 30 \mathrm{~s}$ at $72{ }^{\circ} \mathrm{C} ; 5 \mathrm{~min}$ at $72{ }^{\circ} \mathrm{C}, 4{ }^{\circ} \mathrm{C}$. The annealing temperature for Ent $\mathrm{P}, \mathrm{L} 50 \mathrm{~B}$ and B was $56^{\circ} \mathrm{C}$ instead of $58^{\circ} \mathrm{C}$. The PCR product was visualized by $2 \%$ agarose electrophoresis ( $1 \mu \mathrm{g}$ ethidium bromide). As positive controls, we used E. faecium EK13 = CCM7419 [35] for Ent A, P; E. faecium L50 [42,43] for Ent L50B and B. Briefly, template $(2 \mu \mathrm{L})$ was added to $8.75 \mu \mathrm{L}$ of the reagent mixture, which contained $0.5 \mu \mathrm{L}$ of each primer, $1 \mu \mathrm{L}$ of $(10 \mathrm{mmoL} / \mathrm{L}) \mathrm{dNTPs}$ (Invitrogen) and water to a total volume of $50 \mu \mathrm{L}$. The sequences of the primer pairs used for PCR amplification of the Ents structural genes are as follows: Ent A, F5'-GGT ACC ACT CAT AGT GC AAA-3' ', R 5'-CCC TGG AAT TGC TCC ACC TAA-3'; Ent P, F5'-GCT ACG CGT TCA TAT GGT AAT-3', R5'-TCC TGC AAT ATT CTC TTT AGC-3'; Ent L50B, F5'-ATG GGA GCA ATC GCA AAA TTA-3', R5'-TAG CCA TTT TTC AAT TTG ATC-3'; Ent B, F5'-CAA AAT GTA AAA GAA TTA AGA TCG-3' ${ }^{\prime}$, R5'-AGA GTA TAC ATT TGC TAA CCC-3' . DNA (template) was extracted by the rapid alkaline lysis method [44].

\subsection{Bacteriocin Activity of E. durans}

Ents genes possessing strains were tested for antimicrobial activity using the quantitative agar diffusion method [45]. For this test, concentrates of the strains were prepared as follows: strains ( $0.1 \%$ pre-inoculum) were inoculated in the Brain heart broth (Difco, MD, USA) overnight at $37^{\circ} \mathrm{C}$. Then they were centrifuged for $30 \mathrm{~min}$ at $10,000 \times g$ (at laboratory temperature). Supernatants were concentrated 10-fold using Concentrator plus (Eppendorf AG, Hamburg, Germany) to achieve a volume of $4 \mathrm{~mL}$. Their activity was tested against the principal (the most susceptible indicator Enterococcus avium EA5, fecal strain of piglet, our laboratory), and against Listeriae from different food products (Table 1) Listeria monocytogenes CCM4699 (Czech Culture Collection, Brno, Czech Republic), L. innocua LMG13568 (University Brussel, Belgium) and Staphylococcus aureus SA5 (our strain isolated from mastitis milk). Bacteriocin activity was expressed in arbitrary units per $\mathrm{mL}$, indicating the highest dilution of bacteriocin that can inhibit the growth of the indicator strain. Based on the results of inhibition activity, ED26E/7 was selected to prepare semi-purified bacteriocin (precipitate). Inhibition activity testing was performed in duplicate. 
Table 1. Concentrated substances of $E$. durans strains and their inhibition activity $(\mathrm{AU} / \mathrm{mL}) \pm \mathrm{SD}$.

\begin{tabular}{cccc}
\hline \multicolumn{3}{c}{ Producers } \\
\hline ED25E/6 & ED26E/7 & ED7E/9 \\
\hline EA5 & ng & $800 \pm 28.2$ & $100 \pm 12.1$ \\
CC4699 & $100 \pm 10.0$ & $100 \pm 12.2$ & $100 \pm 12.0$ \\
P2024 & ng & $100 \pm 12.0$ & $100 \pm 10.0$ \\
P2116 & ng & $100 \pm 10.0$ & ng \\
P6301 & ng & $100 \pm 10.0$ & $100 \pm 10.0$ \\
P6501 & ng & $100 \pm 10.0$ & ng \\
P3300 & ng & $100 \pm 12.0$ & ng \\
\hline
\end{tabular}

E. durans ED24E/9 and ED26E/1 were negative; ng-negative; EA5, Enterococcus avium; CCM4699, Listeria monocytogenes, LMG13568, L. innocua, P2024-P3300, L. monocytogenes; AU/mL, Arbitrary unit per mL; SDstandard deviation.

\subsection{Partial Purification of Bacteriocin ED26E/7 and Activity Testing}

At first, partial purification of the bacteriocin substance followed the protocol according to Mareková et al. [39] for Ent P; the activity of $1600 \mathrm{AU} / \mathrm{mL}$ against E. avium EA5 strain was measured. Therefore, partial purification was performed according to the protocol for durancin 28L [22], there was a modification regarding the temperature and time of cultivation (although the durancin gene was not tested). ED26E/7 was cultivated in $500 \mathrm{~mL}$ of MRS (Merck, Germany) at $37^{\circ} \mathrm{C}$ for $18 \mathrm{~h}$. Then the broth culture was centrifuged $(10,000 \times g)$ for $30 \mathrm{~min}(\mathrm{~min})$ at $4{ }^{\circ} \mathrm{C}$. The $\mathrm{pH}$ of the supernatant was adjusted to 4.2 and filtrated using a $0.45 \mu \mathrm{m}$ filter (Millipore Corp. Bedford, MA, USA). The supernatant was precipitated with ammonium sulfate $\left(80 \%\right.$ saturation) at $4{ }^{\circ} \mathrm{C}$ overnight $(18 \mathrm{~h})$. After precipitation and centrifuging $(10,000 \times g)$ for $30 \mathrm{~min}$ at $4{ }^{\circ} \mathrm{C}$, the precipitate was re-suspended in the minimum volume of phosphate buffer ( $\mathrm{pH}$ 6.5) and inhibition activity was tested against E. avium EA5. Inhibition activity reached 102,400 AU/mL. Moreover, other indicators were used: S. aureus SA5, L. innocua LMG13568, L. monocytogenes (12) from various food products, various staphylococci from ewe's milk lump cheese and raw goat milk, E. faecium, E. faecalis, E. hirae from raw goat milk and meat products, E. thailandicus from beavers, and fecal strains $E$. mundtii from roe and red deers.

\subsection{In Vitro Safety Control}

To control safety of E. durans ED26E/7, three specific genes for virulence factors were tested. PCR amplification with the primers and conditions used followed the protocols according to Kubašová et al. [46] and Lauková et al. [47]. The genes tested were GelE (gelatinase), hylEfm (hyaluronidase) and Is16 (element IS). The PCR products were separated by means of agarose gel electrophoresis $(1.2 \% w / v$, Sigma-Aldrich, Saint Louis, MO, USA) with $1 \mu \mathrm{L} / \mathrm{mL}$ content of ethidium bromide (Sigma-Aldrich) using $0.5 \times$ TAE buffer (Merck, Darmstadt, Germany). PCR fragments were visualized with UV light. E. faecium P36 (Dr. Semedo-Lemsaddek, University Lisbon, Portugal) was the positive control. The PCRs were carried out in $25 \mu \mathrm{L}$ volume with a mixture consisting of $1 \times$ reaction buffer, $0.2 \mathrm{mmoL} / \mathrm{L}$ of deoxynucleoside triphosphate, $3 \mathrm{mmoL} \mathrm{MgCl}_{2}, 1 \mu \mathrm{moL} / \mathrm{L}$ of each primer, $1 \mathrm{U}$ of Taq DNA polymerase and $1.5 \mu \mathrm{L}$ of the DNA template, with the cycling conditions as previously reported by Kubašová et al. [42] and Lauková et al. [43].

\subsection{In Vivo Safety Control}

For the in vivo safety control of E. durans ED26E/7 strain, pathogen-free eight-weekold male Balb/c mice (VELAZ Prague, Czech Republic) were used. Their weight was around 18-20 g. Mice maintenance conditions were the same as previously reported by Vargová et al. [48]. Mice were kept under a 12-h light/dark regimen at a temperature of $22-24{ }^{\circ} \mathrm{C}$ with a humidity of $56 \%$. They were on a commercial diet, and water was available without restriction. Mice were divided randomly into 2 groups: Control $(n=10)$ and Group $1(n=10)$. To differ the ED26E/7 strain from other enterococci, its rifampicin-resistant 
variant was prepared [49]. ED26E/7 was administered per os daily at a dose of $10^{9} \mathrm{CFU} / \mathrm{mL}$ in a total dose $100 \mu \mathrm{L}$. Counts of ED26E/7, as well as other enterococci, were enumerated after standard microbiological dilution of feces and jejunum (jejunum was homogenized using Masticator, Spain) and plated on BHI agar enriched with rifampicin $(100 \mu \mathrm{g})$, and M-Enterococcus agar. Counts were expressed in CFU/g $(\log 10) \pm$ SD. Sampling occurred at the start of the experiment $(n=20)$ and on days 7 and 30 .

\section{Results}

\subsection{Identification of E. durans Strains}

The total enterococcal count in the screened cheeses reached $3.93 \mathrm{CFU} / \mathrm{g}(\log 10)$ \pm 1.98 on average. Based on MALDI-TOF mass spectrometry evaluation, strains were allotted to the species E. durans with evaluation scores from 1.781 up to 2.245 (Figure 1). Among the nine allotted colonies, five strains (ED24E/9, ED25E/6, ED26E/1, ED26E/7 and ED7E/9) were selected for the next testing. Four identical colonies were excluded. E. durans ED26E/7 reached a score of 2.125, ED7E/9 had a score of 1.781, ED26E/1 possessed a score of 1.921, ED25E/ 6 was scored with a value of 2.245 and ED24E/9 had a score of 2.154. To support taxonomical allotment, phenotyping was provided, and the results were compared with the type strain E. durans ATCC 19432. In these five strains, the $N$-acetylglucosamine test was positive, as well as the fermentation of galactose, D-glucose and lactose, while mannitol, inulin and sorbitol were not fermented (they were negative), as well as raffinose. The Voges-Proskauer test was positive; the hydrolysis of esculin showed a dubious reaction and hippurate hydrolysis as well.

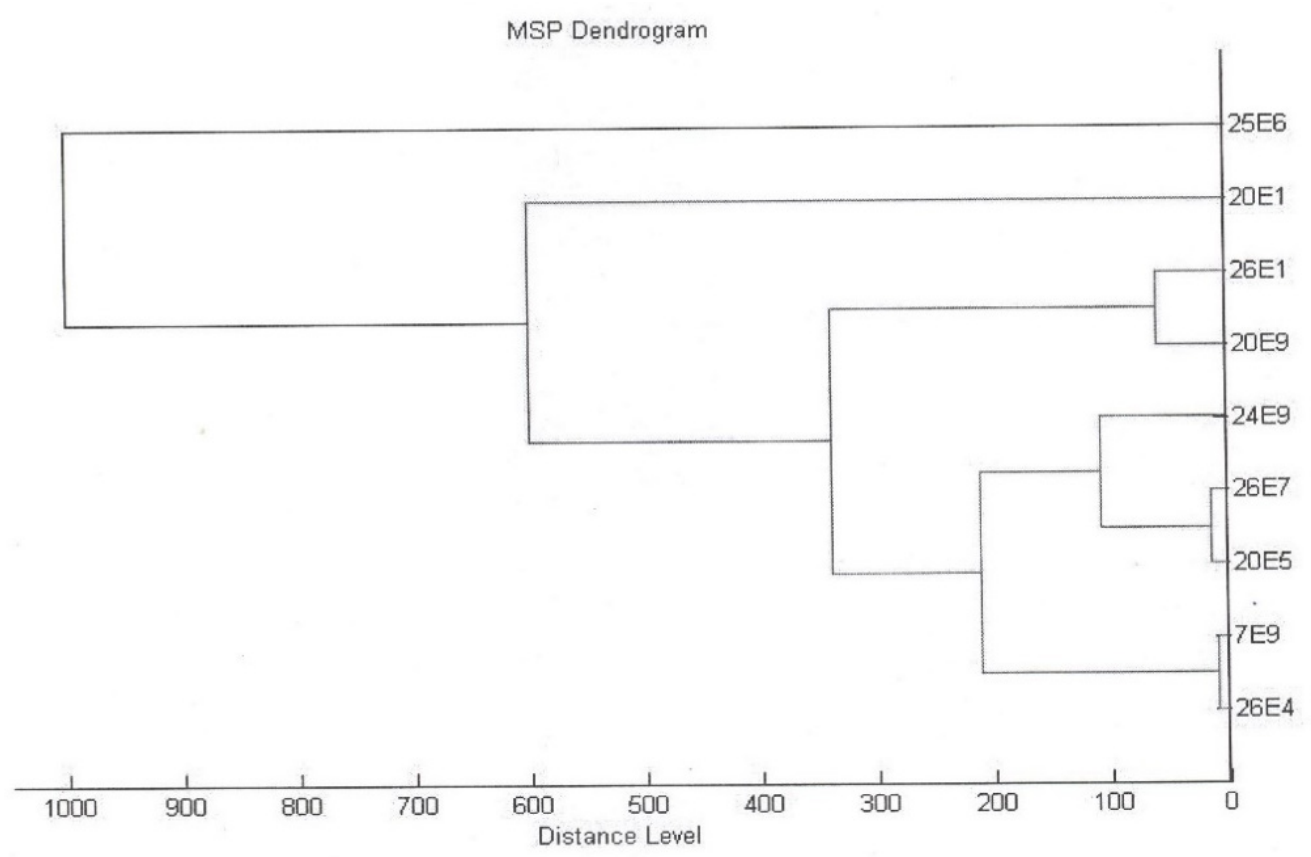

Figure 1. Dendrogram of enterococcal strains from ewe's milk lump cheese. The vertical axis displays distance between clusters. The horizontal bars indicate the point at which two clusters are merged. (Indicated E. durans strains, ED25E/6, ED26E/1, ED7E/9, ED26E/7 and ED24E/9).

E. durans strains produced the enzyme alkaline phosphatase at a slight amount, $5 \mathrm{nmoL}$, similar to lipase, leucine arylamidase, valine arylamidase, cystin arylamidase, $\alpha$-chymotrypsin, trypsin and acid phosphatase. The enzyme $\beta$-glucuronidase was not produced (except for in ED24E/9), and $\alpha$-mannosidase and $\alpha$-fucosidase were produced in $5 \mathrm{nmoL}$ or not produced. However, beneficial hydrolase, $\beta$-galactosidase was produced by $\mathrm{ED} 26 \mathrm{E} / 7$ strain at the amount $10 \mathrm{nmoL}$; the other strains either produced $5 \mathrm{nmoL}$ or did not produce this enzyme. Esterase, esterase lipase and naphtol-AS-Bi-phosphohydrolase 
were also produced in amounts of 5 or $10 \mathrm{nmoL}$. The amount of $\beta$-galactosidase was the highest in the ED26E/7 strain (10 nmoL).

\subsection{Hemolysis, Gelatinase and Antibiotic Phenotype}

All E. durans strains did not form hemolysis ( $\gamma$-hemolysis). The gelatinase test was also negative. The strains were susceptible to all antibiotics using the disk diffusion method with inhibition zones ranging from 10 up to $28 \mathrm{~mm}$ except for resistance to clindamycin in one strain, novobiocin, streptomycin or kanamycin. However, E. durans ED26E/7 was susceptible to all antibiotics with an inhibition size ranging from 13 up to $28 \mathrm{~mm}$. The antibiotic profile of this strain was also evaluated using an E-test. E. durans ED26E/7 was susceptible to penicillin $(8 \mu \mathrm{g} / \mathrm{mL})$, ampicillin $(2 \mu \mathrm{g} / \mathrm{mL})$, tetracycline $(5 \mu \mathrm{g} / \mathrm{mL})$, erythromycin and vancomycin $(4 \mu \mathrm{g} / \mathrm{mL})$. MIC breakpoints $(\mu \mathrm{g} / \mathrm{mL})$ for these antibiotics are: $\mathrm{P}, \mathrm{S} \leq 8 / \mathrm{R} \geq 16$; Amp, $\mathrm{S} \leq 4 / \mathrm{R} \geq 16$; TCT, $\mathrm{S} \leq 4 / \mathrm{R} \geq 16$;E, $\mathrm{S} \leq 0.5 / \mathrm{R} \geq 8$; Van, $S \leq 4 / R \geq 32$.

\subsection{Structural Genes, Bacteriocin Activity}

Ent $A$ and Ent $P$ genes were detected in tested $E$. durans strains. Ent $P$ genes were found in the strains E. durans ED25E/6, ED26E/1, ED7E/9 and ED26E/7, and the Ent $A$ gene was detected in the strain ED24E/9. ED24E/9 and ED26E/1 did not show inhibition activity against the indicators used. Inhibition activity of strain concentrates ED25E/6, ED7E/9 and ED26E/7 are shown in Table 1. The principal indicator E. avium was inhibited by concentrates of the strains ED26E/7 and ED7E/9 with inhibition activities of $800 \pm 28.2$ and $100 \pm 12.1 \mathrm{AU} / \mathrm{mL}$. L. monocytogenes CCM4699 was inhibited by concentrates of all three ED strains (100 AU/mL). The other listeriae (five strains) were not inhibited by ED25E/6, and ED7E/9 concentrates; however, concentrate ED26E/7 inhibited the growth of three listeriae $(100 \pm 10.0,100 \pm 12.2,100 \pm 12.0 \mathrm{AU} / \mathrm{mL})$.

\subsection{Activity of Partially Purified Bacteriocin-ED26E/7}

The highest inhibition activity of the bacteriocin substance ED26E/7 was reached using a purification protocol for durancin L28 [20]. The activity 102,400 $\pm 320.0 \mathrm{AU} / \mathrm{mL}$ was measured; in the first protocol (Materials and Methods), it was only $1600 \pm 40.0 \mathrm{AU} / \mathrm{mL}$ against the EA5 strain. Ninety-four different indicators were used to test the activity of PPB (partially purified bacteriocin); 73 Gram-positive enterococci and staphylococci, and 21 Gram-negative E. coli. Fifty-one enterococcal species strains (E. faecium, E. faecalis, E. hirae, E. mundtii and E. thailandicus) were used and 22 staphylococcal species strains (S. aureus, S. simulans, S. xylosus, S. capitis, S. warneri, S. sciuri, S. arlettae, S. schleiferi, S. hominis and S. delphini) from ewe's milk lump cheeses and from raw goat milk. S. aureus SA5 (from mastitis) was inhibited with activity 25,600 $\pm 116.6 \mathrm{AU} / \mathrm{mL}$ (Table 2a); Listeria innocua LMG13568 (25,600 $\pm 160.0 \mathrm{AU} / \mathrm{mL}), 12$ strains of L. monocytogenes from different products $(25,600 \mathrm{AU} / \mathrm{mL}$, see Table $2 \mathrm{a})$, then 5 strains of E. thailandicus from beavers with activity $12,800 \mathrm{AU} / \mathrm{mL}$ (Table $2 \mathrm{~b}$ ), fecal $E$. mundtii strains from roe and red deers (7) were inhibited with inhibition activity in the range from 100 up to $400 \mathrm{AU} / \mathrm{mL}$ (Table 2b), 9 strains of E. faecium from fermented meat products (400-6400 AU/mL, Table 2b,c), 9 E. faecium from raw goat milk (200-102,400 AU/mL, Table 2c), 2 strains of E. faecalis from meat products $(3200,6400 \mathrm{AU} / \mathrm{mL}$ ) and 4 strains of $E$. hirae (3 from the meat products and 1 from raw milk) with activity 200-6400 AU/mL. Using 22 staphylococcal strains isolated from raw goat milk, only four strains were inhibited (100 AU/mL); 12 strains were from cheeses (Table 2d). Twenty-one fecal Escherichia coli from piglets were tested; however, they were not inhibited.

\subsection{In Vitro and In Vivo Safety Control (Virulence Factor)}

ED26E/7 did not possess genes for $h y l$ and IS 16 elements. It also did not possess the GelE gene. ED26E/7 survived well in feces of Balb/c mice; at day 30, it reached almost $10^{5} \mathrm{CFU} / \mathrm{g}(\log 10)(4.61 \pm 0.14 \mathrm{CFU} / \mathrm{g})$. It does not cause the mortality of mice. 
Table 2. (a) Inhibition activity of durancin substance produced by ED26E/7 strain against the principal strains (EA5, SA5) and Listeria spp. in arbitrary unit per $\mathrm{mL}(\mathrm{AU} / \mathrm{mL}) \pm \mathrm{SD}$. (b) Inhibition activity of the durancin substance produced by ED26E/7 against enterococci in arbitrary unit per $\mathrm{mL}(\mathrm{AU} / \mathrm{mL}) \pm \mathrm{SD}$. (c) Inhibition activity of the durancin substance produced by ED26E/7 against enterococci in arbitrary unit per $\mathrm{mL}(\mathrm{AU} / \mathrm{mL}) \pm \mathrm{SD}$. (d) Inhibition activity of the durancin substance produced by ED26E/7 against various staphylococci from ewe's milk lump cheeses and raw goat milk in arbitrary unit per $\mathrm{mL}(\mathrm{AU} / \mathrm{mL}) \pm \mathrm{SD}$.

\begin{tabular}{|c|c|}
\hline \multicolumn{2}{|c|}{ (a) } \\
\hline Indicator Strains & Activity \\
\hline EA5 & $25,600 \pm 160.0$ \\
\hline SA 5 & $25,600 \pm 116.6$ \\
\hline L. innocua & $25,600 \pm 160.0$ \\
\hline L. monocytogenes & \\
\hline P2024 & $25,600 \pm 160.0$ \\
\hline P7401 & $25,600 \pm 120.0$ \\
\hline P7562 & $25,600 \pm 160.0$ \\
\hline 108111 & $25,600 \pm 160.0$ \\
\hline 3500 & $25,600 \pm 116.0$ \\
\hline 5285 & $25,600 \pm 120.0$ \\
\hline Ve405 & $25,600 \pm 120.0$ \\
\hline 7395 & $25,600 \pm 40.0$ \\
\hline 2116 & $25,600 \pm 120.0$ \\
\hline 6501 & $25,600 \pm 116.6$ \\
\hline 7223 & $25,600 \pm 40.0$ \\
\hline 6301 & $25,600 \pm 120.0$ \\
\hline \multicolumn{2}{|c|}{ (b) } \\
\hline Indicator Strains & Activity \\
\hline ETHc10/1 & $12,800 \pm 35.8$ \\
\hline ETHc10/2 & $12,800 \pm 40.0$ \\
\hline ETHc12/1 & $12,800 \pm 35.8$ \\
\hline ETHc12/2 & $12,800 \pm 40.0$ \\
\hline ETTr10/1 & $12,800 \pm 35.8$ \\
\hline EM3/166/1 & $100 \pm 10.0$ \\
\hline $\mathrm{EM} 4 / 112 / 1$ & $200 \pm 14.1$ \\
\hline EM1/133/1 & $100 \pm 10.0$ \\
\hline $\mathrm{EM} / 107 / 2$ & $400 \pm 20.0$ \\
\hline EM1/90/2 & $200 \pm 14.0$ \\
\hline EM5/114/1 & $100 \pm 10.0$ \\
\hline EM6/123/1 & $100 \pm 10.0$ \\
\hline EF 1Bs & $3200 \pm 56.6$ \\
\hline EF1Ns & $6400 \pm 80.0$ \\
\hline $\mathrm{EF} 2 \mathrm{Sc}$ & $3200 \pm 56.6$ \\
\hline EF2Kal & $1600 \pm 40.0$ \\
\hline EFKL5 & $800 \pm 28.2$ \\
\hline EFPL3 & $3200 \pm 56.6$ \\
\hline EFPL4 & $800 \pm 20.0$ \\
\hline
\end{tabular}


Table 2. Cont.

(c)

\begin{tabular}{cc}
\hline Indicator Strains & Activity \\
\hline EEPL1 & $6400 \pm 80.0$ \\
EEKL2 & $6400 \pm 80.0$ \\
EHPL2 & $6400 \pm 69.3$ \\
EHTOK1 & $400 \pm 20.0$ \\
EHTOK2 & $1600 \pm 40.0$ \\
EH21 & $200 \pm 14.2$ \\
EF6/2 & $25,600 \pm 160.0$ \\
EF10/2 & $6400 \pm 80.0$ \\
EF11/1 & $400 \pm 20.0$ \\
EF12/1 & $800 \pm 28.2$ \\
EF14/2 & $6400 \pm 69.0$ \\
EF15/1 & $3200 \pm 56.6$ \\
EF16/1 $18 / 1$ & $6400 \pm 69.0$ \\
EF23 & $51,200 \pm 220.0$ \\
\end{tabular}

(d)

\begin{tabular}{cc}
\hline Indicator Strains & Activity \\
\hline SXOs7/2 & $12,800 \pm 40.0$ \\
SXOs2/3 & $800 \pm 28.0$ \\
SciOs17/4 & $100 \pm 10.0$ \\
Sci Os6/3 & $12,800 \pm 113.0$ \\
Sci Os5/1 & $12,800 \pm 40.0$ \\
SciOs8/1 & $200 \pm 10.0$ \\
SciOs18/1 & $12,800 \pm 35.8$ \\
SmiOs17/6 & $400 \pm 20.0$ \\
SmiOs14/1 & $25,600 \pm 160.0$ \\
SmiOs18/4 & $100 \pm 10.0$ \\
SAOs2/1 & $6400 \pm 79.8$ \\
SqOs54 & $100 \pm 10.0$ \\
Sca31/2 & $100 \pm 12.2$ \\
SW39 & $100 \pm 10.0$ \\
Sq 40/2 & $100 \pm 10.0$ \\
SD30 & $100 \pm 10.0$ \\
\hline
\end{tabular}

(a) EA5, Enterococcus avium; CCM4699, Listeria monocytogenes, LMG13568, L. innocua, P2024-6301, L. monocytogenes; $\mathrm{AU} / \mathrm{mL}$, arbitrary unit per $\mathrm{mL}, \pm \mathrm{SD}$-standard deviation; (b) ET, Enterococcus thailandicus from beavers, EME. mundtii from roe and red deer. $\mathrm{EF}-E$. faecium from various meat products; $\pm \mathrm{SD}-$ standard deviation; (c) EE, Enterococcus faecalis EEPL1-EEKL2) from various meat products, EH, E. hirae from raw goat milk and meat products (EHTOK1, EHTOK2, EH21), E. faecium from raw goat milk (EF6/2-EF23); \pm SD-standard deviation; (d) SX, Staphylococcus xylosus, Sci, S. sciuri, Smi, S. simulans, Sq, S. equorum, Sca, S. capitis, SW, S. warneri, SA, S. aureus, SD, S. delphini) \pm SD—standard deviation.

\section{Discussion}

Enterococcal counts in ewe's milk cheese were similar as, e.g., in fermented meat products [50], but a lower count $(1.82 \mathrm{CFU} / \mathrm{mL}, \log 10)$ was detected in raw goat milk [5]. Lihui Du et al. [24] isolated anti-listerial bacteriocin, the durancin GL producer of which E. durans 41D was isolated from Hispanic style cheese. In this study, three out of five identified strains showed identification scores corresponding to secure genus identification/probable species identification (ED26E/7, ED25E/6, ED 24E/9); the scores of the strains ED7E/9 and ED26E/1 corresponded with probable genus identification. However, phenotypic biochemical testing supported characteristics for the species E. durans [31].

To evaluate strains as safe, no antibiotic resistance and/or virulence factor genes can be present, or their phenotype has to be assessed, as well as no or slight production of damaging enzymes (disease markers). The production of intestinal disorder enzymes, such as $\beta$-glucuronidase, $\alpha$-chymotrypsin or $\beta$-glucosidase, was slight in the $E$. durans tested. $N$-acetyl- $\beta$-glucosaminidase was negative or only $5 \mathrm{nmoL}$; that one enzyme is 
required to proliferate in vivo [51]. The tested strains seem to be safe regarding enzyme evaluation. In addition, ED26E/7 produced beneficial lactase ( $\beta$-galactosidase) at the value of $10 \mathrm{nmoL}$; this enzyme is used in the dairy industry for the production of lactosefree milk to be consumed by lactose-intolerant people [52]. It is known that bacterial $\beta$-glucuronidase can play a role in colon cancer; therefore, a zero (0) value for this enzyme measured in E. durans strains is also promising from a safety aspect. Enterococci considered for industrial applications should be antibiotic-resistant or have virulence factor genes absent [53]. In general, the production of gelatinase increased the pathogenicity in the animal model [54]. Furthermore, gelatinase can cleave fibrin, which was suggested to have important implications in the virulence of E. faecalis, as the secreted protease can damage host tissue and thus allow bacterial migration and spread infection. However, ED26E/7 was hemolysis and gelatinase-negative. The bacteriocin-producing species strain E. durans was also isolated from important Egyptian cheese OSY-W [55]. Pieniz et al. [56] described E. durans LAB18s isolated from Brazilian soft cheese with the antioxidant activity of its culture supernatant and intracellular extract. Further beneficial/desirable traits may include the production of antioxidants or the expression of pathogens antagonism [55]. Dvorožňáková et al. [57] reported the highest stimulative effect on phagocytosis induced by E. durans ED26E/7 strain in mice infected with Trichinella spiralis. Moreover, the respiratory burst of blood polymorphonuclear cells was stimulated, which can contribute to a decreased larval migration and destruction of muscle larvae, and therefore, reduced parasite burden in the host. The application of ED26E/7 caused a significant decrease in the number of muscle larvae of T. spiralis and showed the highest inhibition effect on female fecundity (94\%) [58]. Moreover, the respected increase in macrophage's metabolic activity induced by ED26E/7 in the intestinal phase of trichinellosis augmented the hostparasite defense (damage and killing newborn larvae with reactive oxygen species from macrophages [48]). The implication of enterococci in food safety was previously reported by Franz et al. [13]. However, the principal condition is that the strain for use has to be safe [59]. In our previous studies, the anti-listerial effect of enterocin CCM4231 was reported in Saint-Paulin cheese or traditional Slovak dairy product "Bryndza" [60,61]. In Saint-Paulin cheese experimentally infected with $L$. monocytogenes Ohio, its initial count of $6.7(\log 10) \mathrm{CFU} / \mathrm{g}$ was decreased to $1.9 \mathrm{CFU} / \mathrm{g}$ in one week after enterocin addition. In "Bryndza", bacterial reduction (expressed in order of magnitude) was noted after Enterocin CCM4231 application.

It can be summarized that bioactive E. durans ED26E/7 was selected from ewe's milk lump cheese. This gelatinase and hemolysis-negative ( $\gamma$-hemolysis) strain, most susceptible to commercial antibiotics producing $10 \mathrm{nmoL}$ lactase enzyme $\beta$-galactosidase, represents a promising additive for dairy products. ED26E/7 did not possess virulence factor genes, such as hyl (hyaluronidase), the IS16 element or GelE gene. Its partially purified bacteriocin substance inhibited the growth of Gram-positive indicator bacteria; the principal indicator E. avium EA5, S. aureus SA5 and the other 16 out of 22 staphylococci, listeriae, and also 36 out of 51 enterococcal indicators were inhibited. In the experimental Balb/c mice, ED26E/7 did not cause mortality.

\section{Conclusions}

It can be concluded that $E$. durans ED26E/7 represents a promising beneficial strain for dairy products manufacturing as a natural, bacteriocin-producing adjunct, which can prolong the stability of the products (cheese) by influencing microbiota without negative influence on cheese quality, and with respect for the One Health concept strategy. This study also contributes new alternative approaches for safety assessment in food hygiene/technology and based on previous results, also in feed or food-producing animal production system. 
Author Contributions: A.L.: Conceptualization, Investigation, Methodology, Data curation, Writing and Project administration; M.T.: Resources and Methodology; V.K.: Methodology, V.S.: Methodology, M.P.S.: Methodology, E.D.: Methodology. All authors have read and agreed to the published version of the manuscript.

Funding: This study was supported by the Slovak Research and Development Agency under contract no. APVV-17-0028 and by bilateral project SK-PT-18-0005.

Institutional Review Board Statement: Ethical review and approval were waived for this study, due to reason, that cheeses were sampled and milking is normal procedure, so for this study it is not applicable.

Informed Consent Statement: Not applicable.

Data Availability Statement: The complete data produced in this study are available to research applicants.

Acknowledgments: This study was supported by the Slovak Research and Development Agency under contract no. APVV-17-0028 and by bilateral project SK-PT-18-0005. We are grateful to Margita Bodnárová and Dana Melišová for their skillful laboratory work. We also thank Renátka Szabóová for laboratory help. We are also thankful Andrew Billingham for English editing. Preliminary results were reported in the conference Hygiena Alimentorum XXXIV. (2013), pp. 117-121, ISBN 978-80-8077-334-2, as well as in Slovak Veterinary Journal (in Slovak): Bioactive strains of Enterococcus durans isolated from ewe's milk lump cheese, vol. 5, 2012, pp. 277-278.

Conflicts of Interest: The authors declare that they have no conflict of interest.

\section{References}

1. Park, Y.W.; Juaréz, M.; Ramos, M.; Haenlein, G.F. Physico-chemical characteristics of goat and sheep milk. Small Rum. Res. 2007, $68,88-113$.

2. Kováčová, M.; Výrostková, J.; Dudríková, E.; Žigo, F.; Semjon, B.; Regecová, I. Assessment of quality and safety of farm level produced cheeses from sheep and goat milk. Appl. Sci. 2021, 11, 3196. [CrossRef]

3. Bouton, Y.; Buchin, S.; Duboz, G.; Pochet, S.; Beuvier, E. Effect of mesophilic lactobacilli and enterococci adjunct cultures on the final characteristics of a microfiltered milk Swiss-type cheese. Food Microbiol. 2009, 26, 183-191. [CrossRef]

4. Salazar, J.K.; Carstens, C.K.; Ramachadran, P.; Shazer, A.G.; Narula, S.S.; Reed, E.; Ottesen, A.; Schill, K.M. Metagenomics of pasteurized and unpasteurized gouda cheese using targeted 16S rDNA sequencing. BMC Microbiol. 2018, 18, 189. [CrossRef] [PubMed]

5. Lauková, A.; Micenková, L.; Pogány Simonová, M.; Focková, V.; Ščerbová, J.; Tomáška, M.; Dvorožňáková, E.; Kološta, M. Microbiome associated with Slovak traditional ewe's milk lump cheese. Processes 2021, 9, 1603. [CrossRef]

6. Planý, M.; Kuchta, T.; Šoltýs, K.; Szemes, T.; Pangallo, D.; Siekel, P. Metagenomics analysis of Slovak bryndza cheese using next-generation 16S rDNA amplicon sequencing. Nova Biotechnol. Chim. 2016, 15, 23-34. [CrossRef]

7. Parente, E.; Ricciardi, A.; Zotte, T. The microbiota of dairy milk: A review. Int. Dairy J. 2020, 104, 104714. [CrossRef]

8. Giraffa, G. Enterococci from foods. FEMS Microbiol. Rev. 2002, 26, 163-171. [CrossRef]

9. Rivas, F.P.; Castro, M.P.; Vallejo, M.; Marguet, E.; Campos, C.A. Antibacterial potential of Enterococcus faecium strains isolated from ewes' milk and cheese. LWT-Food Sci. Technol. 2012, 46, 428-436. [CrossRef]

10. Lauková, A.; Focková, V.; Pogány Simonová, M. Enterococcal species associated with Slovak raw goat milk, their safety and susceptibility to lantibiotics and Durancin ED26E/7. Processes 2021, 9, 681. [CrossRef]

11. Bondi, M.; Lauková, A.; de Niederhausern, S.; Messi, P.; Papadopoulou, C.H.; Economou, V. Controversial aspects displayed by enterococci: Probiotics or pahogens. BioMed Res. Int. 2020, 2020, 9816185. [CrossRef]

12. Ben Braiek, O.; Smaoui, S. Enterococci:between emerging pathogens and potential probiotics. BioMed. Res. Int. 2019, 2019, 5938210. [CrossRef]

13. Franz, C.M.A.P.; Huch, M.; Abriouel, H.; Holzapfel, W.; Gálvez, A. Enterococci as probiotics and their implications in food safety. Int. J. Food Microbiol. 2011, 151, 125-140. [CrossRef] [PubMed]

14. Hajikhani, R.; Beyatli, Y.; Aslim, B. Antimicrobial activity of enterococci strains isolated from white cheese. Int. J. Dairy Technol. 2007, 60, 105-108. [CrossRef]

15. Foulquié Moreno, M.R.; Sarantinopoulos, P.; Tsakalidou, E.; De Vuyst, L. The role and application of enterococci in food and health. Int. J. Food Microbiol. 2006, 106, 1-24. [CrossRef]

16. Lauková, A.; Chrastinová, L'.; Pogány Simonová, M.; Strompfová, V.; Plachá, I.; Čobanová, K.; Formelová, Z.; Chrenková, M.; Ondruška, L'. Enterococcus faecium AL41:Its Enterocin M and their beneficial use in rabbits husbandry. Prob. Antimicro. Prot. 2012, 4, 243-249. [CrossRef]

17. Pogány Simonová, M.; Chrastinová, L'.; Lauková, A. Autochthonous strain Enterococcus faecium EF2019 (CCM7420), its bacteriocin and their beneficial effect in broiler rabbits-A review. Animals 2020, 10, 1188. [CrossRef] [PubMed] 
18. Franz, C.M.A.P.; van Belkum, M.J.; Holzapfel, W.H.; Abriouel, H.; Gálvez, A. Diversity of enterococcal bacteriocins and their grouping in a new classification scheme. FEMS Microbiol. Rev. 2007, 31, 293-310. [CrossRef] [PubMed]

19. Hussein, W.E.; Abdelhamid, A.G.; Roch-Mendoza, D.; Garcia-Cano, I.; Yousef, A.E. Assessment of safety and probiotic traits of Enterococcus durans OSY-EGY, isolated from Egyptian artinasal cheese, using comparative genomics and phenotypic analysis. Front. Microbiol. 2020, 11, 608314. [CrossRef]

20. Yanagida, F.; Chen, T.; Onda, T.; Shinohara, T. Durancin L28-1A, a new bacteriocin from Enterococcus durans L28-1, isolated from soil. Lett. Appl. Microbiol. 2005, 40, 430-435. [CrossRef]

21. Tanasupawat, S.; Sukontasing, S.; Lee, J.S. Enterococcus thailandicus sp. nov. isolated from fermented sausage (mum) in Thailand. Int. J. Syst. Evol. Microbiol. 2008, 58, 1630-1634. [CrossRef]

22. Hu, C.B.; Zendo, T.; Nakayama, J.; Sonomoto, K. Description of durancin TW-49M, a novel enterocin $\beta$-homologous bacteriocin in carrot-isolated Enterococcus durans QU 49. J. Appl. Microbiol. 2008, 105, 681-690. [CrossRef] [PubMed]

23. Khay, E.O.; Pastrana-Castro, M.; Fajardo-Bernárdez, P.; Skali Senhaji, N.; Idaomar, M.; Abrini, J. Growth of Enterococcus durans E204 producing bacteriocin-like substance in MRS broth:Description of the growth and quantification of the bacteriocin-like substance. Afr. J. Bacteriol. 2012, 11, 659-665. [CrossRef]

24. Du, L.; Liu, F.; Zhao, P.; Zhao, T.; Doyle, M.P. Characterization of Enterococcus durans 152 bacteriocins and their inhibition of Listeria monocytogenes in ham. Food Microbiol. 2017, 68, 97-103. [CrossRef] [PubMed]

25. Lauková, A.; Pogány Simonová, M.; Focková, V.; Kološta, M.; Tomáška, M.; Dvorožňáková, E. Susceptibility to bacteriocins in biofilm-forming, variable staphylococci detected in local Slovak ewes' lump cheeses. Foods 2020, 9, 1335. [CrossRef]

26. The Slovak Spectator. 2011. Available online: https://spectator.sme.sk (accessed on 6 August 2011).

27. Oravcová, M.; Margetin, M.; Tančin, T. The effect of stage of lactation on daily milk yielded, and milk fat and protein content in Tsigai and improved Valachian ewes. Mljekarstvo 2015, 65, 48-56. [CrossRef]

28. Grieger, C.; Burdová, O. Hygiene of Milk and Dairy Products; University of Veterinary Medicine, Nature: Bratislava, Slovak, 1978; Volume 64-200-78, p. 103-23-8.2.

29. Alatoom, A.A.; Cunningham, S.A.; Ihde, S.; Mandrekar, J.; Patel, R. Comparison of direct colony method versus extraction method for identification of Gram-positive cocci by use of Bruker Biotyper matrix-assissted laser desorption ionization-time of flight mass spectrometry. J. Clin. Microbiol. 2011, 49, 2868-2873. [CrossRef]

30. Lauková, A.; Kandričáková, A.; Bino, E.; Tomáška, M.; Kološta, M.; Kmet', V.; Strompfová, V. Some safety aspects of enterococci isolated from Slovak lactic acid dairy product "žinčica". Folia Microbiol. 2020, 65, 79-85. [CrossRef]

31. Manero, A.; Blanch, A.R. Identification of Enterococcus spp. with a biochemical key. Appl. Environ. Microbiol. 1999, 65, 4425-4430. [CrossRef]

32. Semedo-Lemsadek, T.; Santos, M.A.; Martins, P.; Lopes, M.F.S.; Marques, J.F.; Tenreiro, R.; Crespo, M.T.B. Comparative study using type strains and clinical and food isolates to examine hemolytic activity and occurrence of the cyl operon in enterococci. $J$. Clin. Microbiol. 2003, 41, 2569-2576. [CrossRef]

33. Waters, C.M.; Antiporta, M.H.; Murray, B.E.; Dunny, G.M. Role of the E. faecalis GelE protease in determination of cellular chain length, supernatant pheromone levels, and degradation of fibrin and misfold surface proteins. J. Bacteriol. 2003, 185, 3613-3623. [CrossRef]

34. Kanemitsu, K.; Kunishima, H.; Tomakiho, M.; Okamura, N. Quantitative determination of genatinase activity in enterococci. J. Microb. Methods 2001, 47, 11-16. [CrossRef]

35. CLSI. Clinical and Laboratory Standards Institute guideline. In Performance Standards for Antimicrobial Susceptibility Testing M100S, 26th ed.; Electronic: Wayne, PA, USA, 2016; ISBN 978-1-68440-067-6.

36. EFSA. Guidance on the assessment of bacterial susceptibility to antimicrobials of human and veterinary importance. EFSA J. 2012, 10, 2740.

37. Lauková, A.; Mareková, M.; Javorský, P. Detection and antimicrobial spectrum of a bacteriocin-like substance produced by Enterococcus faecium CCM 4231. Lett. Appl. Microbiol. 1993, 16, 257-260. [CrossRef]

38. Lauková, A.; Simonová, M.; Strompfová, V.; Štyriak, I.; Ouwehand, A.C.; Várady, M. Potential of enterococci isolated from horses. Anaerobe 2008, 1, 234-236. [CrossRef]

39. Mareková, M.; Lauková, A.; De Vuyst, L.; Skaugen, M.; Nes, I.F. Partial characterization of bacteriocins produced by environmental strain Enterococcus faecium EK13. J. Appl. Microbiol. 2003, 94, 523-530. [CrossRef] [PubMed]

40. Aymerich, T.; Holo, H.; Havarstain, L.S.; Hugas, M.; Garriga, M.; Nes, I.F. Biochemical and genetic characterization of enterocin A from Enterococcus faecium, a new antilisterial bacteriocin in the pediocin family of bacteriocins. Appl. Environ. Microbiol. 1996, 62, 1676-1682. [CrossRef] [PubMed]

41. Casaus, P.; Nilsen, T.; Cintas, L.M.; Nes, I.; Hernandez, P.E.; Holo, H. Enterocin B, a new bacteriocin from Enterococcus faecium T136 which can act synergistically with enterocin A. Microbiology 1997, 143, 2287-2294. [CrossRef]

42. Cintas, L.M.; Casaus, P.; Havarstein, L.S.; Hérnandéz, P.E.; Nes, I.F. Biochemical and genetic characterization of enterocin P, a novel sec-dependent bacteriocin from Enterococcus faecium P1 with a broad antimicrobial spectrum. Appl. Environ. Microbiol. 1997, $43,4231-4330$.

43. Cintas, L.M.; Casaus, P.; Holo, H.; Hernandez, P.E.; Nes, I.F.; Havarstein, L.S. Enterocins L50A and L50B, two novel bacteriocins from Enterococcus faecium L50 are related to staphylococcal haemolysins. J. Bacteriol. 1998, 180, 1988-1994. [CrossRef] 
44. Baele, M.; Chiers, K.; Devriese, L.A.; Smith, H.E.; Wisselink, H.J.; Vaneechoutte, M.; Haesebrouck, F. The gram-positive tonsillar and nasal flora of piglets before and after weaning. J. Appl. Microbiol. 2001, 91, 997-1003. [CrossRef]

45. De Vuyst, L.; Callewaert, R.; Pot, B. Characterization of antagonistic activity of Lactobacillus amylovorus DCE471 and large-scale isolation of its bacteriocin amylovorin L471. Syst. Appl. Microbiol. 1996, 19, 9-20. [CrossRef]

46. Kubašová, I.; Diep, D.B.; Ovčinnikov, K.V.; Lauková, A.; Strompfová, V. Bacteriocin production and distribution of bacteriocinencoding genes in enterococci from dogs. Int. J. Antimicrob. Agents 2020, 55, 105859. [CrossRef]

47. Lauková, A.; Strompfová, V.; Ščerbová, V.; Pogány Simonová, M. Virulence factor gene incidence among enterococci from sewage sludge in eastern Slovakia following safety aspect. BioMed Res. Int. 2019, 2019, 2735895. [CrossRef] [PubMed]

48. Vargová, M.; Hurníková, Z.; Revajová, V.; Lauková, A.; Dvorožňáková, E. Probiotic bacteria can modulate murine macrophage's superoxide production in Trichinella spiralis infection. Helminthologia 2020, 57, 226-234. [CrossRef]

49. Strompfová, V.; Lauková, A.; Mudroňová, D. Effect of bacteriocin-like substance produced by Enterococcus faecium EF55 on the composition of avian gastrointestinal microflora. Acta Vet. Brno 2003, 72, 559-564. [CrossRef]

50. Lauková, A.; Czikková, S.; Laczková, S.; Turek, P. Use of enterocin CCM 4231 to control Listeria monocytogenes in experimentally contaminated dry fermented Hornád salami. Int. J. Food Microbiol. 1999, 52, 115-119. [CrossRef]

51. Roberts, G.; Homer, K.A.; Tarelli, E.; Philpott-Howard, J.; Devriese, L.A.; Brighton, D. Distribution of endo- $\beta-N-$ acetylglucosaminidase amongst enterococci. J. Med. Microbiol. 2001, 50, 620-626. [CrossRef] [PubMed]

52. Kamel, Z.; Magdy, N.M.; Farahat, M.G. Optimization of culture conditions for production of $\beta$-galactosidase by Bacillus megaterium NM56 isolated from raw milk. Res. J. Pharm. Biol. Chem. Sci. 2016, 7, 366-376.

53. Domann, E.; Hain, T.; Ghai, R.; Billion, A.; Kuenne, C.; Zimmermann, K.; Chakraborty, T. Comparative genomic analysis for the presence of potential Enterococcal virulence factors in the probiotic Enterococcus faecalis strain Symbioflor 1. Int. J. Med. Microbiol. 2007, 297, 533-539. [CrossRef]

54. Singh, K.V.; Qin, X.; Weinstock, G.M.; Murray, B.E. Generation and testing of mutants of Enterococcus faecalis in a mouse peritonitis model. J. Infect. Dis. 1998, 178, 1416-1420. [CrossRef]

55. Hussein, W.E.; Xiaoli, L.; Yousef, A.E. Draft genome Sequence of Enterococcus durans OSY-EGY, a multiple-antimicrobial-peptide producer isolated from Egyptian hard cheese. Microbiol. Resourc. Announc. 2019, 8, e00303-19. [CrossRef]

56. Pieniz, S.; Andreazza, R.; Anghioni, T.; Camargo, F.; Brandelli, A. Probiotic potential, antimicrobial and antioxidant activities of Enterococcus durans strain LAB18s. Food Control 2014, 37, 251-256. [CrossRef]

57. Dvorožňáková, E.; Bucková, B.; Hurníková, Z.; Revajová, V.; Lauková, A. Effect of probiotic bacteria on phagocytosis and respiratory burst activity of blood polymorphonuclear leucocytes (PMNL) in mice infected with Trichinella spiralis. Vet. Parasitol. 2016, 231, 69-76. [CrossRef] [PubMed]

58. Bucková, B.; Hurníková, Z.; Lauková, A.; Revajová, V.; Dvorožnáková, E. The anti-parasitic effect of probiotic bacteria via limiting the fecundicity of Trichinella spiralis female adults. Helmithologia 2018, 55, 102-111. [CrossRef]

59. Piskoríková, M. Quality and characterization of existing and new probiotics (EFSA QPS). In Proceedings of the Regulatory Framework Workshop Health Claim Approval of Probiotics in the European Union issue, Kosice, Slovakia, 18 June 2010.

60. Lauková, A.; Vlaemynck, G.; Czikková, S. Effect of enterocin CCM4231 on Listeria monocytogenes in Saint-Paulin cheese. Folia Microbiol. 2001, 46, 157-160. [CrossRef] [PubMed]

61. Lauková, A.; Czikková, S. Antagonistic effect of enterocin CCM 4231 from Enterococcus faecium on "bryndza", a traditional Slovak dairy product from sheep milk. Microbiol. Res. 2001, 156, 31-34. [CrossRef] [PubMed] 